\title{
A new titanosaur sauropod from the Atacama Desert, Chile
}

\author{
ALEXANDER W.A. KELLNER ${ }^{1}$, DAVID RUBILAR-ROGERS ${ }^{2}$, ALEXANDER VARGAS $^{3}$ and MARIO SUÁREZ ${ }^{4}$ \\ ${ }^{1}$ Setor de Paleovertebrados, Departamento de Geologia e Paleontologia, Museu Nacional/Universidade Federal do Rio de Janeiro, \\ Quinta da Boa Vista s/n, São Cristóvão, 20940-040 Rio de Janeiro, RJ, Brasil \\ ${ }^{2}$ Área Paleontología, Museo Nacional de Historia Natural, Casilla 787, Santiago, Chile \\ ${ }^{3}$ Departamento de Biología, Facultad de Ciencias, Universidad de Chile, Las Palmeras 3425, Nuñoa, Casilla 653, Santiago, Chile \\ ${ }^{4}$ Museo Paleontológico de Caldera, Av. Wheelwrigth 001, Caldera, Chile \\ Manuscript received on December 22, 2010; accepted for publication on January 12, 2011
}

\begin{abstract}
Partial remains of a titanosaur sauropod collected in the Tolar Formation (Upper Cretaceous) at the Atacama Desert (Antofagasta Region), northern Chile, is described, and a new species, Atacamatitan chilensis gen. et sp. nov., is erected. The material consists mainly of dorsal and caudal vertebrae, part of a humerus and a femur. The presence of a titanosaur confirms the Cretaceous age for the outcrops of red sandstone of the Tolar Formation whose age was previously uncertain, ranging from the Upper Cretaceous to the Paleocene. The new specimen represents the most complete dinosaur reported for this region and one of the most complete titanosaur known from Chile and the pacific margin of South America so far.
\end{abstract}

Key words: Dinosauria, Titanosauria, Atacamatitan, Atacama Desert, Cretaceous, Chile.

\section{INTRODUCTION}

The record of continental fossil vertebrates in Mesozoic deposits of Chile is very rare. From these, although scarce, titanosaur sauropods are the best documented, mostly limited to incomplete and isolated remains recovered from only four localities, all from the northern part of the country (Rubilar-Rogers 2003, 2005). They include the first report of non-avian dinosaur bones, consisting of an incomplete left scapula and coracoid, and the distal end of a right humerus that were regarded as cf. Antarctosaurs wichmannianus and as Titanosauridae indet., respectively (Casamiquela et al. 1969).

In order to prospect for continental Mesozoic tetrapod fossils in Chile, contacts between Chilean and Brazilian researchers were established in 1998 and a preliminary expedition during February 2000 was organized by the Museo Nacional de Historia Natural (San-

Proceedings of the Third Gondwanan Dinosaur Symposium Correspondence to: Alexander Wilhelm Armin Kellner E-mail: kellner@mn.ufrj.br tiago) and the Museu Nacional/UFRJ (Rio de Janeiro) to the Antofagasta region. During this field activity, a site located about $150 \mathrm{~km}$ north of Calama town and some $50 \mathrm{~km}$ east from El Abra cooper mine was discovered (Vargas et al. 2000). The deposits in this area represent the Tolar Formation that consists of a sequence of sedimentary clastic red rocks with intercalations of conglomerates of the same color and brechas at the base (Maksaev 1978). Up to that time, the age inferred for this formation had not been defined with precision, ranging from the Upper Cretaceous to the Paleocene. The dinosaur specimen supports a Cretaceous age at least for the outcrops of the Tolar Formation near Conchi Viejo town, where the dinosaur site is located.

The year thereafter (July, 2001), a second expedition continued to excavate the site. This activity resulted in what is the second most complete titanosaur dinosaur recovered from Chile so far (a more complete specimen is known from III Región de Copiapó, D. Rubilar-Rogers et al., unpublished data.). The material was collected in 
a surface of $2 \mathrm{~m}^{2}$ and is regarded as representing one individual, which is described here.

\section{SYSTEMATIC PALEONTOLOGY}

Dinosauria Owen, 1842

Sauropoda Marsh, 1878

Titanosauria Bonaparte \& Coria, 1993

Titanosauriformes Salgado et al., 1997

Titanosauridae Lydekker, 1893

Atacamatitan gen. nov.

Etymology: Atacama, from the desert where the specimen was found, and Titan, which relates to a group of Greek divinities.

Type species: Atacamatitan chilensis sp. nov., type by monotypy.

Recorded temporal and stratigraphic range: Upper Cretaceous, Tolar Formation.

Diagnosis: As for the type and only known species.

Atacamatitan chilensis sp. nov.

Etymology: In allusion to Chile, the country where the specimen was found.

Holotype: The material includes a right femur, the proximal end of a humerus, two dorsal vertebrae, posterior caudal vertebrae, dorsal ribs and a fragmentary element regarded as part of the sternum, besides other incomplete bones, all housed at the Sección Paleontología, Museo Nacional de Historia Natural, under the number SGO-PV-961 (Figs. 1-4). A cast of one caudal vertebra (MN 7232-V) is deposited in the Museu Nacional/UFRJ (Rio de Janeiro).

Occurrence: The material comes from an outcrop near Conchi Viejo town, Atacama Desert, Antofagasta Region, and was collected in a surface of $2 \mathrm{~m}^{2}$.

Recorded temporal and stratigraphic range: Upper Cretaceous, Tolar Formation.

Diagnosis: Titanosaurid dinosaur with the following combination of characters that distinguishes it from other members of this clade (autapomorphies are marked with an asterisk): centrum of dorsal vertebrae pierced by pleurocoels, which are rounded or elliptical but do not acuminate posteriorly*; ventral surface of the dorsal vertebra strongly concave*; posterior caudals with a laterally compressed neural spine that bears a blade-like anterior margin*; femur with the shaft getting gradually narrower until two thirds of its length*.

\section{DESCRIPTION AND COMPARISONS}

When the site was found, the first specimen of Atacamatitan chilensis gen. et sp. nov. to be recognized was the femur, which was eroding on the surface. Subsequently, other bones were excavated, including several fragments. Some are slightly distorted due to taphonomy, but their original shape can be established without difficulty. The bones have a reddish color and are quite heavy, a result of extensive permineralization.

Only two dorsal vertebrae were recovered. They are incomplete, with the neural arches only partially preserved. Both are opisthocoelic, lacking hyposphenehypantrum as in several members of the Titanosauridae (e.g., Salgado et al. 1997). In SGO-PV-961a (Figs. 1A, B) the centrum is remarkably opisthocoelic, with the anterior articulation more convex in lateral view than in SGO-PV-961b. Also, in the former, the centrum is more elongated. It bears on the lateral side developed pleurocoels that are more rounded and less elongated compared with other titanosaurids. These pleurocoels do not acuminate posteriorly in the preserved elements of the new species, contrary to what is observed in several other members of this clade (e.g., Trigonosaurus, see also Calvo et al. 2007b). The main axis of the pleurocoel has $83 \mathrm{~mm}$ and occupies a dorsal position in the centrum. The neural arch is broken and only part of the peduncles is preserved. Their attachment to the centrum is longer than the total length of the pleurocoels. The centrodiapophyseal lamina is undivided. Together with the peduncles, this lamina is inclined anteriorly.

Judging from the preserved portion, the neural arch is wider than high. There is no evidence of the parapophyses at the centrum or at the lower portion of the neural arch indicating that this is a middle or posterior dorsal vertebra. The ventral margin of the centrum is concave. Posteriorly, the centrum bears a pronounced excavation.

The second preserved dorsal vertebra of Atacamatitan chilensis (SGO-PV-961b, Figs. 1C, D) is antero- 


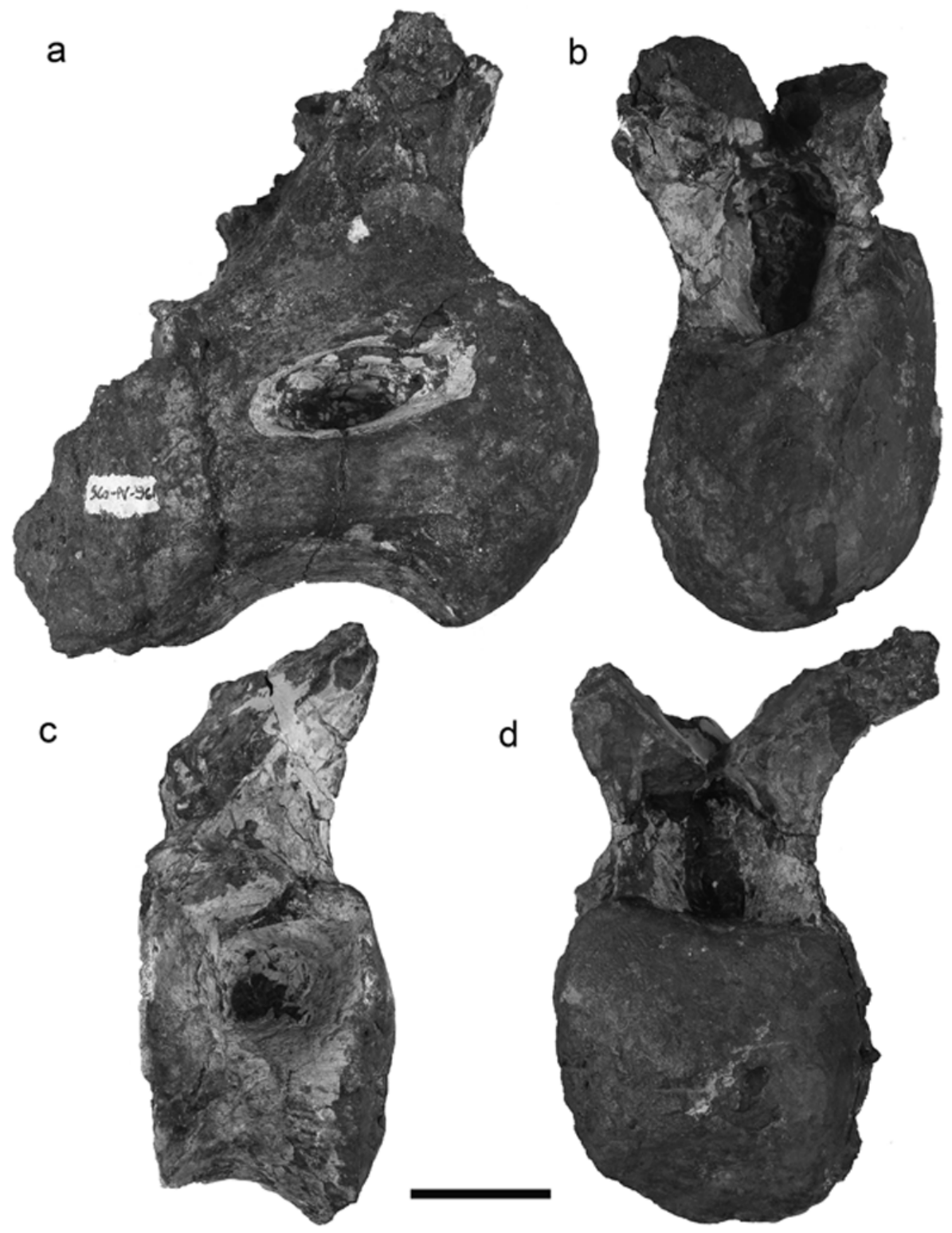

Fig. 1-Atacamatitan chilensis gen. et sp. nov., lateral and anterior views of dorsal vertebrae of SGO.PV. 961a (A, B) and SGO-PV-961b (C,D). Scale bars: $50 \mathrm{~mm}$.

posteriorly compressed. The neural arch is not complete and only the peduncles, the prezygapophyses and part of the left diapophysis are preserved. The base of the peduncles is long and covers almost the total length of the centrum. There is little distance between both prezygapophyses, forming, in anterior view, an angle of approximately $35^{\circ}$. Part of the prezygapophyseal lamina is preserved in the left prezygapophysis. There is no evidence of parapophyses situated on the centrum or in the preserved base of the neural arch. The pleurocoel is circular and deep. The most proximal part of the diapophyses presents an inclination of $30^{\circ}$. The posterior face of the centrum is less excavated than in SGOPV-961a. The short inter-prezygapophyseal distance, the reduced excavation of the posterior centrum face, the dorsolaterally projected transverse process and the absence of the parapophyses suggest that this vertebra belongs to the posterior part of the dorsal series. 
Comparing the dorsal vertebrae of Atacamatitan chilensis with other titanosaurids, they differ from Trigonosaurus, Gondwanatitan, Uberabatitan and Saltasaurus by the strongly concave ventral margin of the centrum, for all in SGO-PV-961a (Powell 1992, Kellner and Azevedo 1999, Campos et al. 2005, Salgado and Carvalho 2008). In this respect, there are similarities with Muyelensaurus, Mendozasaurus and, to some extent, with Opisthocoelicaudia (Salgado et al. 1997, González Riga 2003, Calvo et al. 2007b). Judging from the two preserved dorsal elements, Atacamatitan chilensis differs by having the pleurocoels comparatively more rounded and less elongated that do not acuminate posteriorly.

Some caudal elements were recovered, but only two are preserved well enough to provide anatomical details. Both come from the middle to posterior end of the tail. SGO-PV-961c (Fig. 2A, B) is essentially formed by the centrum. It is procoelous, compressed dorsoventrally and lacks pleurocoels. Remains of the left transverse process and the base of the neural arch can be observed. No chevrons were collected at the site, but the centrum bears two strong processes to receive them. The ventral and lateral surfaces of the centrum are slightly curved. In dorsal view it is possible to observe a deep compression in the middle portion of this element.

The second caudal element (SGO-PV-961h; Figs. $2 \mathrm{C}, \mathrm{D})$ is complete, lacking only the right prezygapophysis. Overall the centrum (length: $86 \mathrm{~mm}$ ) shows a similar morphology to the previous one (SGO-PV-961c). It is smaller and was positioned more posteriorly than the first. The posterior articulation surface is quadrangular and no processes to receive the chevron are present. It shows a very small dorsal tuberosity on the lateral side of the centrum (sensu Kellner et al. 2005). The prezygapophyses are elongated and reach about 30\% of the preceding vertebral centrum. Postzygapophyses are short and located at the ventral margin of the neural spine. The neural arch is placed in the anterior half of the centrum. The neural spine is directed posterodorsally and has the distal tip slightly expanded dorsoventrally.

Most anatomical information regarding caudal vertebrae of titanosaurid sauropods used in systematic studies comes from the anterior or middle elements of the tail, and the preserved elements of Atacamatitan chilen- sis are from the middle-posterior portion of the caudal series. Nonetheless, a few differences from other titanosaurid caudal vertebrae are noted. The most distinct posterior caudals in titanosaurids are found in Saltasaurus and Rocasaurus, with quite large and developed postzygapophyseal articulations and a longitudinal septum on the ventral part of the vertebrae (Powell 1992, Salgado and Azpilicueta 2000), absent in Atacamatitan. The new Chilean species also differs from the less procoelic condition found in the posterior caudals of Malawisaurus (Jacobs et al. 1993), a taxon that occupies a more basal position within the Titanosauria (e.g., Salgado et al. 1997, Calvo et al. 2007b).

Although the caudals of Atacamatitan probably are more posterior than the most posterior caudal of Trigonosaurus, in the new taxon they differ by being more procoelic (Campos et al. 2005). The last preserved caudal of Baurutitan (the 18th) can be distinguished from the more complete element of the Chilean titanosaurid (which might also be more posterior) by having a distinct process on the neural spine, which is also quite elongated anteroposteriorly (Kellner et al. 2005). Mendozasaurus and Muyelensaurus also have distinct neural spines in their preserved posterior caudal elements that are higher and more elongated anteroposteriorly than in Atacamatitan (González Riga 2003, Calvo et al. 2007a). The preserved posterior caudal vertebrae of Gondwanatitan show a straighter ventral margin (Kellner and Azevedo 1999), contrasting with the concave condition observed in Atacamatitan. Furthermore, this Brazilian titanosaurid has a broader and more inclined neural spine.

The most similar caudal elements of the Chilean species are found in Maxakalisaurus and Uberabatitan (Kellner et al. 2006, Salgado and Carvalho 2008). The main difference is the less developed neural spine in Atacamatitan that has a sharp and blade-like anterior margin. Comparisons with some other South American titanosaurids that are based on caudal elements such as Adamantisaurus are very limited, since there is no overlapping element (Santucci and Bertini 2006).

Some isolated elements, which represent ribs, were also collected. The best preserved one is SGO-PV-961d that shows a strong anteroposterior compression, with the dorsoventral diameter longer than the anteroposterior one (Figs. 3A, B). This bone is slightly curved in the 

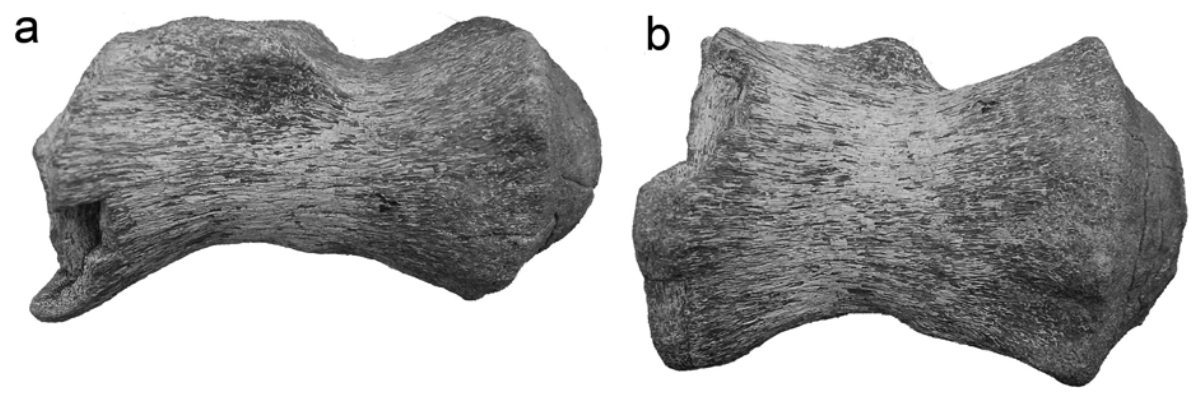

c

d
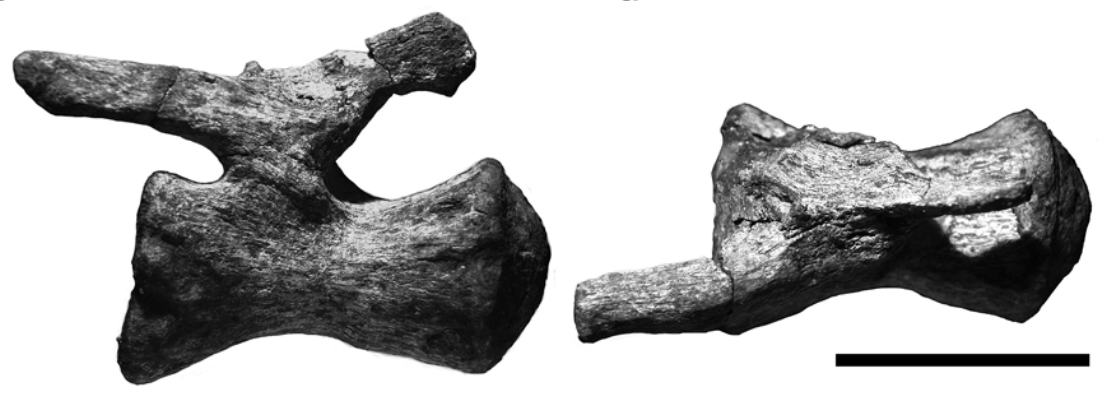

Fig. 2-Atacamatitan chilensis gen. et sp. nov., caudal centrum SGO.PV.961c in ventral (A) and ventrolateral views (B); caudal vertebrae SGO-PV-961h in lateral (C) and dorsal (D) views. Scale bars: $50 \mathrm{~mm}$.

ventral side with a crest that forms a marked angle (about $90^{\circ}$ ) on the dorsal edge. The capitulum and tuberculum are not complete. It is unknown if the ribs of Atacamatitan also bear pneumatic foramina as observed in some other titanosaurids (e.g., Maxakalisaurus).

A fragment of a plate-like bone is interpreted as a portion of the sternal plate (SGO-PV-961e, Fig. 3C). It is thin with a smooth border. Given the fragmentary condition, it is impossible to distinguish if the element corresponds to a crescentic or oval general form (Salgado et al. 1997).

The proximal half of a right humerus (Figs. 4A, B) is preserved (SGO-PV-961f). The proximal end is expanded and has a square outline. Although the deltopectoral crest is not totally preserved, it is noticeable that this element has a reduced distal expansion. In anterior view, the humerus is hollowed out with a well-marked depression for muscular attachment. The midshaft is straight and has an elliptic transverse section. Although comparisons with other titanosaurids are rather limited, the humerus of Atacamatitan belongs to the elongated type, differing from the shorter and blunter condition observed in Saltasaurus (Powell 1992). It further dif- fers from Mendozasaurus, which bears a quite distinctive and elongated deltopectoral crest (González Riga 2003). Also in Gondwanatitan the deltopectoral crest is larger than in the comparable preserved portion of Atacamatitan (Kellner and Azevedo 1999).

The last element preserved of Atacamatitan chilensis is the right femur (SGO-PV-961g). Overall this element is rather gracile compared to the preserved portion of the humerus, suggesting that the new Chilean titanosaur had the forelimbs stronger relative to the hind limbs, a potential autapomorphy of this species. This bone is slender and lacks the femoral head (Fig. 4C). The total length is $1.10 \mathrm{~m}$, and the width at midshaft lateromedially is $12.5 \mathrm{~cm}$. The proximal portion is medially deflected and has a lateral bulge (a typical titanosauriform feature), which extends about $25 \%$ of the total length of the preserved bone. The shaft is anteroposteriorly flattened and mediolaterally wide (the lateromedial diameter is $250 \%$ greater than the anteroposterior one). However, it has a different configuration in respect to several titanosaurids, particularly the Saltasauridae, whose width is continuous along the entire length of the shaft (e.g., Powell 1992). In Atacamatitan the width 


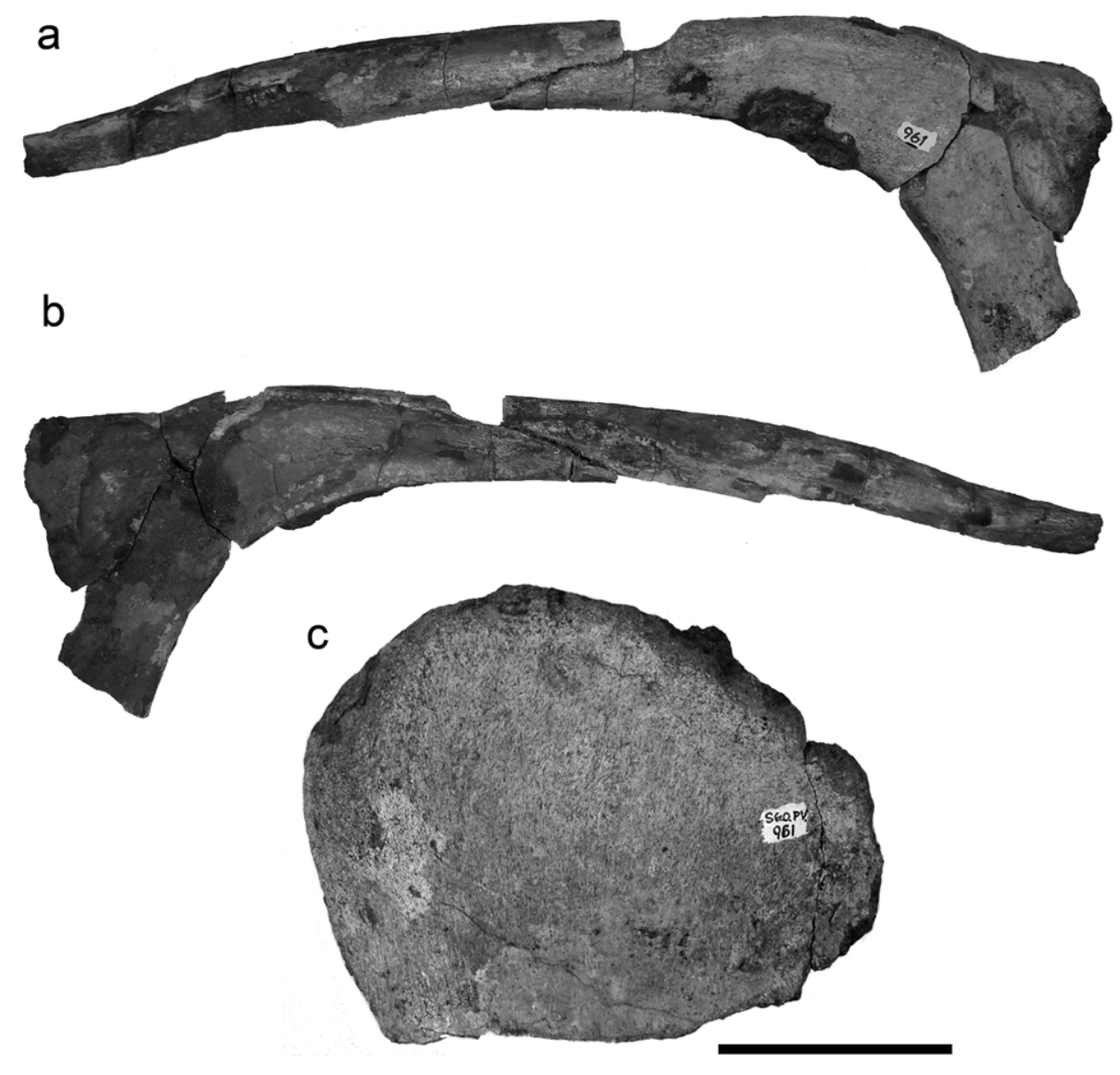

Fig. 3 - Atacamatitan chilensis gen. et sp. nov., rib (SGO-PV-961d) in anterior (A) and posterior (B) views; fragmentary sternal plate (SGO-PV-961e). Scale bar: $100 \mathrm{~mm}$.

along the shaft is variable and smaller than the width between the external surface of the distal condyles. On the distal end, the fibular and tibial condyles are of subequal sizes, with the medial one slightly larger. A welldeveloped fourth trochanter in present posteriorly, extending onto the proximal quarter of the femur. A deep groove runs along the proximal third of the femur and is positioned medial to the greater trochanter. The posterior surface of the distal end of the femur shows a depression that gently separates the medial and lateral condyles.

\section{DISCUSSION}

As pointed out innumerous times in the literature, the recognition of species in the fossil record can be a complex endeavor (see discussion in Kellner 2010). In several cases, a new species is based on incomplete material, which is also the case for titanosaurid sauropods (e.g., Salgado and Azpilicueta 2000, Mateus et al. 2011). Regarding this group, most of the specimens tend to be very incomplete and fragmentary (e.g., Kellner and Campos 1999, 2000). This is also the case of Atacamatitan chilensis, known for a limited number of elements.

Regarding the identification of the dorsal vertebrae, in various sauropods the parapophyses are displaced in relation to the position that they occupy in the vertebra: from being at the centrum in proximal dorsal vertebrae, to above the centrum, high at the neural arch in the distal vertebrae (McIntosh 1990). In both dorsal vertebrae of Atacamatitan chilensis the bases of the neural arches are attached along the centrum, suggesting a posterior half position for these elements along the vertebral column. Although incomplete, these elements show several relevant anatomical features, including the presence of rounded or elliptical pleurocoels that do not acuminate posteriorly and are less elongated than in most other ti- 

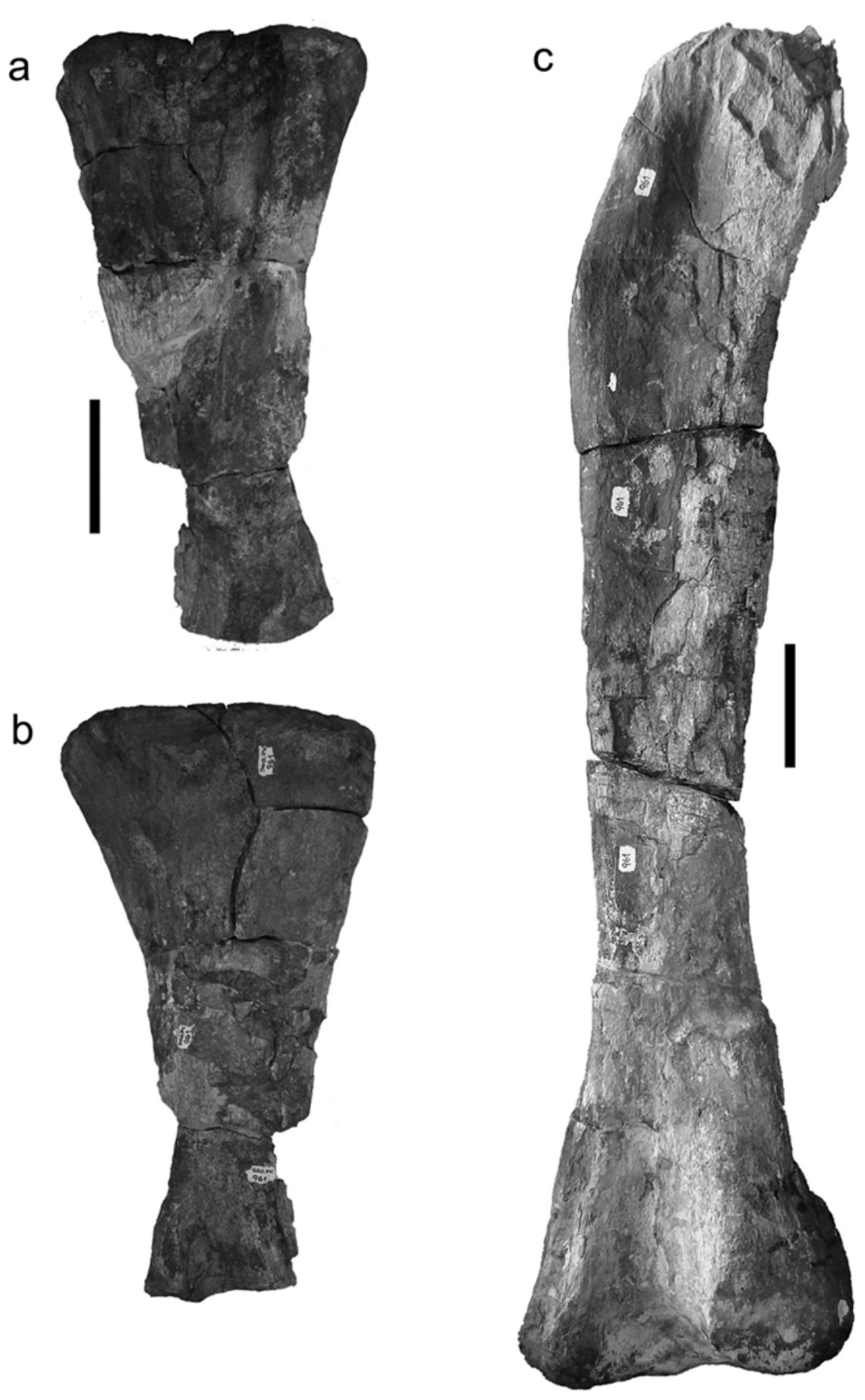

Fig. 4 -Atacamatitan chilensis gen. et sp. nov., proximal half of right humerus (SGO-PV-961f) in anterior (A) and posterior (B) views; femur in anterior view (C) Scale bar: $100 \mathrm{~mm}$.

tanosaurids. Furthermore, the strongly concave ventral surface of the dorsal vertebra indicates that this material belongs to a new titanosaurid species. This is corroborated by the almost complete posterior caudal element that has a laterally compressed neural spine with a sharp and blade-like anterior margin.

The humerus of Atacamatitan chilensis has a poor development of the deltopectoral crest in contrast to de- 
rived titanosaurids such as Gondwanatitan, Opisthocoelicaudia, Saltasaurus, Neuquensaurus and Alamosaurus, whose deltopectoral crest is markedly expanded distally. Such condition is mentioned as a synapomorphy of Saltasauridae by Wilson (2002, but see Salgado et al. 1997).

Another element that shows some distinction from other titanosaurids is the femur, which in Atacamatitan chilensis has a shaft that gets narrower until two thirds of its length.

Although the systematic position of Atacamatitan chilensis is difficult to be established (which is also the case for most titanosaurids), at the time being we can state that this new form is more basal relative to the Saltasauridae, but more derived relative Malawisaurus, and is not a member of the Aeolosaurini.

There is another titanosaurid from the Cretaceous deposits of the Atacama region in Chile. However, the geographic distance (also an aspect to be considered in the recognition of new species - see Kellner 2010) of these records (more than $1.000 \mathrm{~km}$ ) and some discrete anatomical differences (D. Rubilar-Rogers et al., unpublished data) make it unlikely that these specimens represent the same species.

\section{CONCLUSIONS}

Despite the fragmentary and incomplete condition of the specimen SGO-PV-961, it is one of the most complete dinosaur recorded in Chile and does represent a new species, named here Atacamatitan chilensis gen. et sp. nov. The new taxon occupies an intermediate position regarding the Titanosauridae, being less derived than the Saltasauridae but more derived than Malawisaurus. This material confirms the Cretaceous age of the Tolar Formation and shows that these deposits have potential for new findings.

\section{ACKNOWLEDGMENTS}

The authors express their gratitude to Diogenes de Almeida Campos (Museu de Ciências da Terra, Rio de Janeiro) and Jorge O. Calvo (Universidad Nacional del Comahue, Centro Paleontológico Lago Barreales, Neuquén) for allowing the examination of the specimen under their care. We also thank Helder de Paula Silva (Universidade do Grande Rio, Duque de Caxias) for his help during the second field season at the Atacama Desert and for preparing the second caudal vertebra (SGO-PV961h), and Carolina Simon Gutstein for the edition and photographic work. Agustín G. Martinelli (Complexo Cultural e Científico Peirópolis - CCCP/UFTM, Uberaba), Octávio Mateus (Faculdade de Ciências e Tecnologia, Universidade Nova de Lisboa, Portugal) and two anonymous reviewers are thanked for comments that greatly improved this paper.

This study was partially funded by the Fundação Carlos Chagas Filho de Amparo à Pesquisa do Estado do Rio de Janeiro (FAPERJ no. E-26/102.779/2008) and the Conselho Nacional de Desenvolvimento Científico e Tecnológico (CNPq no. 307276/2009-0) (grants to AWAK) and Conicyt (grant to DRR).

\section{RESUMO}

Um esqueleto incompleto de um dinossauro titanossaurídeo de depósitos da Formação Tolar (Cretáceo Superior) do deserto do Atacama (região de Antofagasta), norte do Chile é descrito e uma nova espécie, Atacamatitan chilensis gen. et sp. nov., é proposta. O material consiste principalmente de vértebras dorsais e caudais e de partes do úmero e fêmur. A presença de um titanossauro confirma a idade Cretácea para os afloramentos de arenito avermelhado da Formação Tolar, que eram anteriormente tidos como depositados entre o Cretáceo Superior e o Paleoceno. O exemplar representa o mais completo titanossauro até hoje encontrado na região e um dos mais completos reportados até o momento do Chile e da margem do Oceano Pacífico na América do Sul.

Palavras-chave: Dinosauria, Titanosauria, Atacamatitan, Deserto do Atacama, Cretáceo, Chile.

\section{REFERENCES}

Calvo JO, Porfiri JD And GonzÁlez-Riga B. 2007a. A new titanosaur sauropod from the Late Cretaceous of Neuquén, Patagonia, Argentina. Arq Mus Nac 65: 485504.

CAlvo JO, Porfiri JD, GonzÁlez-Riga B AND KellNER AWA. 2007b. A new Cretaceous terrestrial ecosystem from Gondwana with the description of a new sauropod dinosaur. An Acad Bras Cienc 79: 529-541.

Campos DA, Kellner AWA, Bertini RJ And SANTUCCI RM. 2005. On a titanosaur (Dinosauria, Sauropoda, Titanosauridae) vertebral column from Brazil. Arq Mus Nac 63: 565-593. 
CASAmiquela RM, Corvalán J AND Franquesa F. 1969. Hallazgo de dinosaurios en el Cretácico Superior de Chile. Su importancia cronológica - estratigráfica. Instituto de Investigaciones Geológicas, Boletín 25: 1-31.

GonzÁlez Riga BJ. 2003. A new titanosaur (Dinosauria, Sauropoda) from the Upper Cretaceous of Mendoza Province, Argentina. Ameghiniana 40: 155-172.

JACOBS LL, WINKLER DA, DOWNS WR AND GOMANI EM. 1993. New material of an early Cretaceous titanosaurid sauropod from Malawi. Palaeontology 36: 523534.

Kellner AWA. 2010. Comments on the Pteranodontidae (Pterosauria, Pterodactyloidea) with the description of two new species. An Acad Bras Cienc 82: 1063-1084.

Kellner AWA And Azevedo SAK. 1999. A new sauropod dinosaur (Titanosauria) from the Late Cretaceous of Brazil. National Sciences Museum Monographs 15: 111142.

Kellner AWA and CAmpos DA. 1999. Vertebrate Paleontology in Brazil - a review. Episodes 22: 238-251.

Kellner AWA And Campos DA. 2000. Brief review of dinosaur studies and perspectives in Brazil. An Acad Bras Cienc 72: 509-538.

Kellner AWA, Campos DA, Azevedo SAK, Trotta MNF, HENRIQUES DDR, CRAIK MMT AND Silva HP. 2006. On a new titanosaur sauropod from the Bauru Group, Late Cretaceous of Brazil. Bol Mus Nac, Geol 74: 1-31.

Kellner AWA, CAmpos DA AND Trotta MNF. 2005. Description of a titanosaurid caudal series from the Bauru Group, late Cretaceous of Brazil. Arq Mus Nac 63: 529564.

MaKsaEV V. 1978. Cuadrángulo Chitigua y sector occidental del cuadrángulo Cerro Palpana, Región de Antofagasta. Carta Geológica de Chile n ${ }^{\circ}$ 31, 55 p. 1 mapa 1: 50.000. Instituto de Investigaciones Geológicas.

Mateus O, Jacobs Ll, Schulp AS, Polcyn MJ, TavaRes TS, Neto AB, Morais ML and Antunes MT. 2011. Angolatitan adamastor, a new sauropod dinosaur and the first record from Angola. An Acad Bras Cienc 83: 221-233.
McIntosh JS. 1990. Sauropoda. In: The Dinosauria (WeISHAMPEL D, DOBSON P AND OSMOLSKA H (Eds), University of California Press, Berkeley, p. 345-401.

Powell JE. 1992. Osteología de Saltasaurus loricatus (Sauropoda - Titanosauridae) del Cretácico Superior del Noroeste argentino. In: SANZ JL Y BUSCALIONI AD (Coords), Los Dinosaurios y su entorno biotico. Actas del Segundo Curso de Paleontologia en Cuenca. Ayuntamiento de Cuenca: Instituto "Juan de Valdes", p. 165230.

Rubilar-Rogers D. 2003. Registro de dinosaurios en Chile. Boletín del Museo Nacional de Historia Natural 52: $137-150$.

RUBILAR-Rogers D. 2005. Titanosauriformes remains from Quebrada Cortadera (Tolar Formation, Upper Cretaceous), Atacama Desert, Chile. XXI Jornadas Argentinas de Paleontología de Vertebrados, Plaza Huincul, 38 p.

SAlgado L AND AzPilicueta C. 2000. Un nuevo saltasaurino (Sauropoda, Titanosauridae) de la provincia de Río Negro (Formación Allen, Cretácico Superior), Patagonia, Argentina. Ameghiniana 37: 259-264.

SALGADO L AND CARVALHO IS. 2008. Uberabatitan ribeiroi, a new titanosaur from the Marília Formation (Bauru Group, Upper Cretaceous), Minas Gerais, Brazil. Palaeontology 51: 881-901.

SAlgado L, Coria RA AND CALvo J. 1997. Evolution of titanosaurid sauropods. I: phylogenetic analysis based on the postcranial evidence. Ameghiniana 34: 3-32.

SANTUCCI RM AND BERTINI R. 2006. A new titanosaur from Western São Paulo State, Upper Cretaceous Bauru Group, South-East Brazil. Palaeontology 49: 59-66.

Vargas A, Kellner AWA, Diaz GC, Rubilar D AND SoARES M. 2000. New sauropod dinosaur from the Atacama desert, northern Chile. J Vert Paleont 20(Suppl. 3): 75A.

WILSON J. 2002. Sauropod dinosaur phylogeny: critique and cladistic analysis. Zool Jour of the Linnean Soc 136: 217-276. 